Article

\title{
The Dynamics between State Control and Metropolitan Governance Capacity
}

\author{
Helena Tolkki * and Arto Haveri \\ Faculty of Management and Business, Tampere University, 33014 Tampere, Finland; arto.haveri@tuni.fi \\ * Correspondence: helena.tolkki@gmail.com
}

Received: 13 March 2020; Accepted: 20 April 2020; Published: 26 April 2020

\begin{abstract}
Due to the national importance of metropolitan areas, central governments seek to make them as attractive and competitive as possible. In many cases, this is done through state control over metropolitan areas and their governance arrangements. This article examines the relationship between state control and metropolitan governance capacity based on a comparative case study of four metropolitan areas: Auckland, Dublin, Montreal and Oslo. These areas represent different models of metropolitan governance, as well as different forms of state control. We studied state control by focusing on political and administrative decentralization: how independently can the metropolitan government make decisions and perform its tasks? The conclusion is that the different dimensions of decentralization are connected to capacity, but not straightforwardly. This study indicates that state involvement through different forms of control can increase metropolitan governance capacity, but only if it is combined with mandate and supportive policy actions.
\end{abstract}

Keywords: metropolitan governance; decentralization; capacity; governance structures; control

\section{Introduction}

Metropolitan areas have an important role to nation states, as they are the nodes of human activity and they also drive the economy (see e.g., Kübler and Heinelt 2005, p. 1; OECD 2015a, p. 12). State governments hence aim to enhance the development of metropolitan areas. On the other hand, the importance of metropolitan areas gives them a high level of influence and power in the state (Brenner 2003). Especially in the case of small nations, the metropolitan areas can be interpreted to be so important for the nation that it results in structural conflict, "balance of terror". Therefore, the relationship between state governments and metropolitan areas is often complex, as state governments not only seek to support these areas, but also to control them (Beeri and Magnússon 2019; cf. McKinlay 2011, p. 9).

Metropolitan governance addresses several different challenges, which include multi-layered and multi-leveled social and spatial issues (Walsh and Williams 2013). These issues include housing, transport and land use at the neighborhood, regional and supraregional level, as well as wider issues that are more difficult to grasp, such as enhancing global competitiveness. Moreover, metropolitan governance address complex social matters, such as reducing social segregation (cf. Kübler and Heinelt 2005; Sellers and Hoffmann-Martinot 2005, pp. 11-16; Lefèvre 1998, p. 9).

Mechanisms of metropolitan governance range from hierarchical bodies to networked arrangements, and the administrative tiers upon which metropolitan governance is founded vary between municipal cooperation, regional bodies and the state. According to the OECD (2015b, p. 17), metropolitan governance structures can improve competitiveness, whereas higher levels of governmental fragmentation may make metropolises less productive. Thus, metropolitan governance structures represent the efforts of national and subnational authorities to close the gap between socioeconomic areas and administrative jurisdictions (cf. Brenner 2003; Davoudi 2008). 
Contextual factors, such as administrative traditions, cultures and structures, as well as historical progressions and political power relations, determine what are viewed as suitable, realizable and/or desirable governance structures in different metropolitan areas (cf. Jouvé 2002). Furthermore, different schools of thought in different times have alternated in emphasizing local, regional and city-regional levels as principal metropolitan actors. Searching for a balance between state control and metropolitan autonomy is part of the structural tension embedded in rescaling, in which actors and institutions struggle to define the "best" territorial scale for dealing with contemporary issues (Savitch and Vogel 2009; Sohn and Reitel 2016, p. 308).

Together, these conditions generate a large variety of metropolitan governance arrangements that are positioned differently vis-à-vis the state. While some governments have chosen to increase efficiency by using municipal amalgamations, other governments have allowed existing municipalities to collaborate for one or more purposes, within a more or less institutionalized framework. States also enhance metropolitan competitiveness by enacting economic development initiatives and by being involved in the financing of large infrastructures (Savitch 2010, pp. 13-14; OECD 2015b, pp. 12, 17, 102). Hence, central governments play a significant role not only in funding metropolitan governance structures, but also in steering, maintaining and supporting them.

Based on the studies presented above, it is clear that the relationship between the state and a metropolis is intertwined. In this article, we examine the state's role in building metropolitan governance capacity by comparing four metropolitan governance structures that face different manifestations of state control. The four studied areas are Auckland, Montreal, Dublin and Oslo.

This article contributes to the theory of metropolitan governance by discussing the relationship between the state and a metropolitan area through four ideal types of governance capacity. This knowledge can be applied in achieving governance capacity in metropolitan areas. Using empirical evidence, we respond to the question: What is the role of state control in building metropolitan arrangements' governance capacity?

\section{Theoretical Approaches to Metropolitan Governance Capacity and State Control}

Nelles (2013) defined metropolitan governance capacity as metropolitan arrangement's potential to "act", to construct effective policy and to participate in multilevel policymaking, while Lafortune and Collin (2011, p. 402) as the "capacity to initiate and to offer a collectively discussed and defined solution to the metropolitan stakes affecting a region". Based on these definitions, we understand metropolitan governance capacity as the workability of the governing structure, which involves the arrangement's ability to make decisions, set objectives, frame resources and implement policies at the metropolitan level.

Heinelt and Kübler (2005, p. 190) and Van den Berg and Braun (1999) definitions of metropolitan governance capacity include the importance of higher levels of government as sources of capacity and thus combine state control with metropolitan capacity. Heinelt and Kübler discusses how upper levels of government provide incentives to enhance metropolitan governance capacity, and Van den Berg and Brown discusses how the state provides administrative structure and political support to increase and maintain it. Accordingly, in this study, state control refers to all forms of state steering, from coercive measures to incentives (cf. Lafortune and Collin 2011, p. 402; Sellers and Lidström 2007, p. 615).

State control is usually most evident when the metropolitan governance structure is created, as the state often plays an important role in setting up the structure (Savitch and Kantor 2010; Vogel 2010, p. 64). The state government can provide various incentives to local and regional governments to induce cooperation, but it can also regulate cooperation or amalgamations (cf. Savitch and Vogel 2009). As the governance arrangement continues to exist, the state can hold on to control or it can cede authority and power to the governance structure.

Control is usually seen as a feature of hierarchical government rather than as a form of governance (cf. Stoker 1998, p. 24). However, in a governance relationship, even if no single body may be in complete control, the structures operate in the shadow of hierarchy, as different levels of administration 
seek to dominate governance processes creating a persistent tension between the wish for authoritative action and the dependence on the compliance and action of others (cf. Whitehead 2003; Rhodes 1996).

The nature and intensity of control exercised by state governments over local and regional governments change over time. It appears as fluctuation between centralization and decentralization, rooted in the constant reorganization of administrative structures through administrative tiers and overall changes in society (Goldsmith 2002; Nyholm 2011, p. 128). ${ }^{1}$ Even though metropolitan governance structures often differ from other local and regional bodies in the country, they are still part of the same central-local relationship that defines what kind of governance structures can be applied.

We study the state control through its counterpart decentralization, which is divided into political and administrative decentralization (Loughlin 2007, 2009).

Political decentralization refers to the metropolitan governance structure's autonomic decision-making power and the ability to undertake the political functions of governance, such as representation, in which local officials are chosen locally, have the right to make final decisions regarding policy issues and have the resources to implement those decisions. Administrative decentralization refers to the metropolitan level implementation power and the ability to carry out tasks that are formally under the metropolitan arrangement's jurisdiction (cf. Schneider 2003; Treisman Daniel 2007, p. 2).

In this study, we use the dimensions of decentralization as an analytical basis to address the relationship between state control and metropolitan governance capacity. We analyze political decentralization through the following questions: What is the role of representative democracy in the metropolitan arrangement? How significant is the arrangement's budget, and can it make financial decisions autonomously? Administrative decentralization is analyzed by asking: Is the jurisdiction of the metropolitan governance arrangement equivalent to the tasks it has? What is the arrangement's position vis-à-vis other administrative structures and tiers? Is the distribution of responsibilities clear, or do the jurisdictions overlap?

We study governance capacity by asking: Does the metropolitan-level arrangement have tasks that are central to metropolitan governance? Can it perform these tasks?

\section{Data and Its Limitations}

To compare the four metropolitan areas selected for this study, data were collected from publicly available sources between 2014 and 2016. For most metropolitan areas, comprehensive information on governance structures can be found online. Generally, the information on governance bodies is detailed and up to date. As most of this information comes from the official websites of governance bodies, its accuracy can be trusted with a high level of confidence (cf. OECD 2015b, p. 19). However, governance bodies may present information to depict themselves in a positive light. Therefore, we also used scientific articles and other research reports about the governance structures in question to support the critical analysis.

It is difficult to compare governance structures across different countries for several reasons. First, seemingly similar metropolitan governance models have been successful in some metropolitan areas but have failed in others. No matter which governance level the principal actor is, or which mechanism of governance the metropolitan governance model is founded on, the model can either succeed or fail. Moreover, there is a wide range of governance structures as well as cultural differences that drive those structures (Kübler and Heinelt 2005, pp. 9-10; Haveri et al. 2018).

In addition, the data used in this research limit the study's level of analysis. Data comprising information from the official websites of metropolitan bodies and previous studies on those arrangements do not enable a detailed analysis. Different forms of control, jurisdictions and especially "the amount" of metropolitan capacity cannot be studied on a level that compares to evaluation studies

1 Metropolitan governance paradigms have changed over time (see, e.g., Savitch and Vogel 2009), but there has also been criticism of the OECD's role in circulating paradigms (see, e.g., Pollit 2006). 
in a sense they are traditionally understood. In addition, the comparison of four metropolitan areas does not cover all types of state-metropolitan relationships. Nevertheless, it is possible to draw conclusions about the dynamics between state control and metropolitan governance capacity using this analysis, because the cases serve as examples or ideal types of different manifestations of the relationship.

Due to these limitations, the four metropolitan models are described, and their governance capacity is analyzed individually. The comparisons are only made on a conceptual level. In addition, various aspects are emphasized in the descriptions of the studied metropolitan arrangements because control and capacity appear in different contexts in different areas (cf. Ragin 1987, p. 4). The nature of the descriptions of the cases is historical rather than cross-sectional because the relationship between control and capacity is visible in the institutional changes and reforms that have been conducted in the areas (cf. Salminen 2007, pp. 24-30).

\section{Metropolitan Governance Structures in Auckland, Montreal, Dublin and Oslo}

The studied metropolitan areas were chosen based on their similarities and differences. They are similar in terms of many of their basic features: they are all quite small, with populations between 1.2 and 2.9 million inhabitations; they are all Western democracies; they are all the most important metropolitan areas and engines of economic growth in their respective countries (or province, in the case of Montreal); and they all have mechanisms for metropolitan-wide cooperation. The metropolitan areas are different in terms of their governance structures and mechanisms and especially on how they have developed. The similarities make the comparison possible, and the differences illuminate the dynamics between state control and metropolitan governance capacity.

\subsection{Auckland}

New Zealand's local government sector is comprised of two levels of local authority. There are also five unitary councils that exercise the powers of both levels. The Auckland Council is the largest unitary authority and has a special status among the local government structures in New Zealand. The Council was founded in 2010, when seven existing city and district councils and the previous metropolitan body were disestablished, and a unitary council was established (Derby 2012; McKinlay 2011; Auckland Council 2015).

Metropolitan governance in Auckland is characterized by integrated transport, infrastructure and land-use planning, environmental regulation and globally oriented urban competitiveness. The mayor has a strong leadership role in the Auckland Council, and he is also part of the Council's governing body. In a two-tiered governance structure, the governing body focuses on the big picture and on region-wide strategic decisions. The twenty-one local boards focus on local issues, such as supporting local arts, culture, events and community groups and maintaining local parks and sports fields. The Council-controlled organizations oversee the most significant services and activities, such as transport, investments, property and economic development. They are independent but accountable to the governing body. The Council plans are long term; even the budget's time span is ten years. The funds collected by the Council cover about one-third of the Council's funding; the rest is derived from state allowances, fees and loans. The state is the principal funder of several activities, such as road building and transport infrastructure. The biggest areas of spending are transport and parks, communities and lifestyle (Mouat and Dodson 2013, p. 142; Auckland Council 2015; McKinlay 2011, p. 9).

The relationship between the Auckland metropolitan governance structure and the central government has varied over recent decades and so has the level and nature of the central government's control. The Auckland Regional Authority (ARA) was founded in 1963. It was responsible for metropolitan regional planning and infrastructure service delivery and aimed to harmonize metropolitan decision-making. It was, however, by no means unified, as it had more than forty governing bodies. The ARA was replaced by the Auckland Regional Council (ARC) in 1989. The ARC had a strong democratic mandate, as it was composed of directly elected representatives. However, the ARC had less autonomy than its predecessor, as the central government deliberately weakened the 
metropolitan governance structure as a result of neo-liberal reformation. Many of its service delivery functions were privatized, and its role in urban planning was circumscribed. The body's weakness led to overburdened and ageing water, transport and power infrastructure that adversely affected Auckland's economic competitiveness (Memon et al. 2007, p. 46; Mouat and Dodson 2013, p. 139).

The Auckland Council represents a step further from central government dominance towards intensive metropolitan decentralization. However, the arrangement's governance capacity depends on the culture of governance in the local public sphere. Its relationship with the New Zealand government is essential, as the government has made it clear that it will play an active role in the development of Auckland as a major funder of the Council. The government will not release its control due to the importance of Auckland to the country (McKinlay 2011, p. 9).

\subsection{Montreal}

In Canada, the provinces have significant power over the local and regional governments. This is also the case in Montreal. The metropolitan governance structure, the Communauté métropolitaine de Montréal (CMM), was formed in 2000 as part of a three-level institutional reform that included municipal amalgamations and the creation of borough councils. The province of Quebec initiated the reform, but it was not popular among some of the amalgamated municipalities and political parties. Political power relations changed, and the party that opposed the reform won in the 2003 provincial elections, which led to de-mergers of the newly amalgamated cities (Lambert 2008; Collin and Tomàs 2004; Lafortune and Collin 2011).

The CMM operates as a planning, coordinating and financing agency, and it is responsible for activities such as urban planning, economic development, waste management, societal housing and public transportation. It is managed by a council consisting of mayors and councilors of its member cities and municipalities. Its financing comes mainly from the contributions received from its members based on their fiscal capacity. This accounts for two-thirds of the CMM's budget. The remainder of the financing comes from conditional transfers from the provincial government, loans and other revenues. Overall, the CMM's annual budget is modest (Lafortune and Collin 2011; CMM 2015).

The CMM is responsible for the most important metropolitan governance tasks, but it is relatively weak. The council of the CMM is not directly responsible for the population, and there is no mechanism in the CMM for engaging civil society in decision-making, which creates a distance between the CMM and the people living in the metropolitan area. The consequence of the distance is the absence of societal debates at the metropolitan scale (Lafortune and Collin 2011, p. 405). In terms of metropolitan unitary land-use policy, there has been some progress since the CMM launched its land use and development plan in 2011. The plan frames CMM's planning and clarifies overlapping jurisdictions in land use.

However, the CMM does not have independent or sufficient financing. When it was founded, it aimed to have direct taxing power, but these plans did not come to fruition. The CMM can propose but not impose investments (Ville de Montreal 2015; PMAD 2012). Moreover, the CMM shares its competences in public transportation with the province. Although technically one of the responsibilities of the CMM, the management of public transportation remains the responsibility of the Provincial Transport Agency (AMT). Although the CMM has representation in the AMT council, the jurisdictions of the CMM and AMT overlap, which makes the coordination of public transport unclear and inefficient (AMT 2015; OECD 2004, pp. 16-17). Thus, the CMM's autonomy is overridden by the government of Quebec Province. The CMM was founded as part of the municipal reform initiated by the province, but its mandate never grew to reach the initially intended level.

\subsection{Dublin}

Ireland is an example of a country where the state has a strong grip on the local and regional governments (cf. Bartley and Treadwell Shine 2005, p. 147), and the local governments were recognized as part of the national governmental system only in the 1990s. There are eight regional authorities, 
and the local government is two-tiered. Altogether, its complexity makes Ireland's regional and local government structure unique in the European context. The EU plays an important role in framing Ireland's governance, and the country's metropolitan governance is widely organized through channels that are similar to those of structural funding programs (Dexia 2008, pp. 379-93).

Dublin metropolitan area usually refers to the area covered by the Dublin Regional Authority (DRA) alone or together with the Mid-East Regional Authority (MERA). The DRA consists of board representatives from Dublin City and three counties operating within the region. The DRA became effective in 1994 together with all regional authorities in Ireland. It prepares and implements regional planning strategies with the neighboring MERA and co-ordinates provision of public services between public authorities and other bodies. The DRA monitors the overall development needs of the region. It reviews the development plans of local authorities and is responsible for providing proposals, information and recommendations to the government. Altogether, the regional authority follows the planning guidelines framed by the central government, makes its own plans accordingly and reviews the plans made by the local governments.

Hence, Dublin's entire metropolitan governance is based on agendas provided by the state. The regional and local authorities are mainly operational bodies with no independent mandate, and the central government is also responsible for the funding of metropolitan operations, since the local governments do not have taxation power apart from collecting small-scale taxes (Walsh and Williams 2013; DRA 2015; MERA 2015). Strong central control is also evident in the national government's role in addressing metropolitan issues. The National Transport Authority is directly responsible for the transport infrastructure, investments and the integration of transport and land-use planning in the Greater Dublin Area (Walsh and Williams 2013; NTA 2015).

The Dublin metropolitan area has an important and twofold status in Ireland. Regional politics focus on benefitting the entire country. Hence, the central government invests in cities, especially in Dublin. Therefore, the Dublin metropolitan area has the means to make good use of its potential through straightforward, state-led urban and transport planning. The flip side is that all the local governments, including Dublin, have little say in their own matters, and they are also unequal in terms of status. This, together with strong state control, has affected the regional authorities' willingness to cooperate in metropolitan tasks. The regional authorities have begun to engage in a "them and us" politics of opposition and have thus reduced the potential for effective regional governance (Walsh and Williams 2013; Dublin City 2008).

\subsection{Oslo}

The subnational government structure of Norway consists of municipalities and counties. The city of Oslo has double status as both, a city and a county (Kartverket 2015; Oslo Kommune 2015). The Oslo metropolitan area consists of forty-six municipalities, but there are no metropolitan government structures covering this area. The only structure that operates in the field of metropolitan governance is the Oslo Region Alliance. It was established in 2005 as a joint authority of fifty-seven municipalities, but it expanded and now consists of seventy-eight municipalities. Its governance is based on regional political collaboration that aims to respond to increasing pressure for growth on the national and international levels. The Alliance's focus areas also include spatial development, transport and communications and climate politics. The Alliance's political body, council, consists of the mayors of the area, and the executive body consists of eighteen members. The Alliance has a small budget and is funded through fees collected from its members. The Alliance only convenes once a year or at the request of the board (Samarbeidsalliansen Osloregionen 2015).

Oslo's lack of a strong metropolitan governance arrangement reflects Norway's national politics; although there are only a few large cities in Norway, the tension between urban and rural areas constitutes one of the major cleavages in the political structure, and peripheral values latently dominate the political discussion (Aars 2005, pp. 141-42). Therefore, in the political atmosphere, there is no space for urban or metropolitan politics. For example, the ministry responsible for local and regional 
policy has clear definitions for rural but not for urban policy (Ministry of Local Government and Modernisation 2015). Over the years, there have been some efforts to strengthen metropolitan politics (Kommunal- og Moderniseringsdepartementet 2006; OECD 2007, pp. 139-41), but they have not resulted in the establishment of a strong metropolitan body nor a stronger mandate for the Oslo Region Alliance. As a result, the Alliance has grown bigger, but not stronger.

In addition, the city of Oslo has indicated the need for metropolitan politics in its strategy (City of Oslo 2008, pp. 5, 30-32), and it has joined forces with the Akershus County to address land-use and transport planning (plansamarbeidet) and to organize public transport (Ruter) (Plansamarbeidet 2015; Ruter 2015). The state has also implemented three major investment packages to develop the road network and public transport in the same area that is much smaller than the one considered as the metropolitan area, or the area covered by the Alliance. These investments have not been labeled as metropolitan politics, possibly due to the domination of rural politics over urban politics (cf. Næss et al. 2009; Statens Vegvesen 2015).

\section{Decentralization and Capacity in Auckland, Montreal, Dublin and Oslo}

In terms of political and administrative decentralization, there are significant differences among the governance structures of Auckland, Montreal, Dublin and Oslo. This also leads to differences in their metropolitan governance capacity.

In Auckland, the central government has played a strong role in creating the metropolitan governance structure. The Auckland Council is an example of political decentralization through a two-tier, directly elected governing body. It also has a significant annual budget and autonomy in allocating its funds. The administrative decentralization shows in clear jurisdictions, a strong mandate and a wide operating field. There are no other competing governance arrangements that have the same responsibilities as the Council, and the state does not control the operations of the Council. However, the state still plays an active role in metropolitan governance as the Council's principal funder and has expressed its willingness to maintain a certain level of control over the metropolitan area, as the metropolitan area has such a great importance for the nation (cf. Beeri and Magnússon 2019).

Auckland Council's governance capacity is strong. The Auckland Council is responsible for a wide variety of central metropolitan tasks and their implementation. The previous metropolitan arrangement in Auckland was quite weak, which makes Auckland an interesting example of a case in which the use of a directly elected structure did not lead to governance capacity as such. Therefore, the achievements of the Council do not derive from the Council's strong connection to representative democracy or its governance structure, but from the differences between the Council's former and latter operating structures. The most significant difference is the strong mandate from the state.

In Montreal, the province of Quebec has played a strong role in creating the metropolitan governance structure and has maintained control in several ways. The political decision-making is decentralized in the form of the metropolitan council, but the council has no means to fully execute its decisions. This appears for example in the fact that the CMM cannot impose investments in central metropolitan tasks. In addition, the province steers operations that belong to the responsibilities of the CMM. Overall, the metropolitan structure's jurisdictions are unclear and not only overlap with the province but also with other local authorities. As a result, the political dimension of metropolitan governance is mostly decentralized, but the administrative dimension is centralized.

As a result, the CMM also has limited governance capacity. This is problematic because the structure handles important metropolitan tasks, but its capacity to perform the tasks is diminished by province control. The province established the body to take care of the tasks central to metropolitan governance, but it has not let go of control over the matters that are under the CMM's jurisdiction. The CMM's failure to achieve one of its most important goals, the establishment of a joint financial system to balance the economies of the metropolitan center and the surrounding areas, reveals a gap between planned and actual level of decentralization, as well as between planned and actual capacity. 
However, the CMM has gained some governance capacity over time, as joint land-use planning has unified the fragmented field of metropolitan planning.

In Dublin, the metropolitan governance is highly centralized. It does not have independent status, as it is based on program-based central government steering, and the regions, counties and local governments only function as tools for the state-lead programs. The entire local government system, including regional authorities, is relatively new and the central government has the opportunity and legitimacy to control the core responsibilities of the metropolitan arrangement (Haveri et al. 2018). The state also allocates funds for the metropolitan governance tasks because none of the subnational levels have significant fiscal tasks. Hence, in Ireland, metropolitan governance is highly centralized in terms of the political dimension. In addition, metropolitan governance is decentralized in the administrative dimension, as the metropolitan regional authorities perform the tasks that are given to them. Even if the regional councils operate under strict state control, their tasks and jurisdictions are relatively clear.

The metropolitan arrangement in Dublin is able to perform significant metropolitan tasks, but the tasks themselves are defined by the state. Thus, the core of the governance capacity is based on the state level. Because the state possesses power over metropolitan decisions, as well as power over local and regional governments, the jurisdictions between the metropolitan, state-led model and other tiers are clear, and the planning and implementation of metropolitan tasks are straightforward. The metropolitan level performs the tasks that are central to metropolitan governance. In addition, the metropolitan arrangement has had some problems in reaching its full potential due to state control, which has hindered trust among regional actors. Hence, Dublin's metropolitan governance capacity is limited.

The Oslo Region Alliance is an entirely autonomous governance arrangement led by the local governments. The state steers metropolitan development in a small area around Oslo.

Both political and administrative tasks are decentralized, and, in theory, the Alliance could perform metropolitan tasks completely independently. The issue is that the Alliance is not responsible for any significant tasks. Therefore, the arrangement also has no governance capacity and appears to serve as a platform for municipal cooperation rather than function as an actual metropolitan governance structure. Its mandate comes from the municipalities, but it is not a governance arrangement vis-à-vis the state. Because Norway does not largely address urban or metropolitan politics, there is no vertical relationship between the state and the metropolitan governance structure, and therefore there is also no state control.

\section{Conclusions}

This study provides examples of state control through all the possible combinations of political and administrative decentralization (see Table 1). It is notable that different dimensions of decentralization do not necessarily go together with capacity. For example, lack of political decentralization does not automatically lead to lack of governance capacity.

Striking a balance between central government incentives and disincentives can empower metropolitan governance arrangements and create favorable circumstances for them to govern; in other words, control and capacity can coexist. The national government can employ legal mandates, control and incentives to orchestrate capacity from above (as in Auckland). Although a high degree of control from above can allow the central government to have a monopoly on policy, this can also form the basis for metropolitan governance capacity. In this way, the metropolitan arrangement not only operates at the regional level, but also at the state level (as in Dublin). However, high- and low-level governments must undertake different roles, or the high-level governments can block the development of metropolitan capacity (as in Montreal). Weak state control in the form of lacking incentives and disincentives from above leads to insufficient metropolitan governance capacity. A local mandate may not be enough for the metropolitan arrangement to achieve capacity (as in Oslo) (cf. Sellers and Lidström 2007, pp. 611-12; Daugbjerg 2017, p. 1232). 
Table 1. Political and administrative decentralization can lead to different combinations of: (1) having metropolitan tasks; and (2) being able to perform them.

\begin{tabular}{|c|c|c|c|}
\hline & \multicolumn{3}{|c|}{ Political Decentralization } \\
\hline \multirow{3}{*}{$\begin{array}{l}\text { Administrative } \\
\text { decentralization }\end{array}$} & & Yes & No/Limited \\
\hline & Yes & $\begin{array}{c}\text { AUCKLAND } \\
\text { The governance structure has } \\
\text { significant metropolitan tasks and } \\
\text { the ability to perform them }\end{array}$ & $\begin{array}{c}\text { DUBLIN } \\
\text { The metropolitan arrangement } \\
\text { can perform metropolitan tasks } \\
\text { defined by the state level }\end{array}$ \\
\hline & No/Limited & $\begin{array}{l}\text { MONTREAL } \\
\text { The structure was intended to have } \\
\text { a significant role in metropolitan } \\
\text { governance, but it does not have the } \\
\text { means to perform the tasks }\end{array}$ & $\begin{array}{c}\text { OSLO } \\
\text { The governance structure does } \\
\text { not have any metropolitan tasks, } \\
\text { even though it is highly } \\
\text { autonomous }\end{array}$ \\
\hline
\end{tabular}

\section{Discussion}

The results of this study indicate, that the state has a significant impact in building metropolitan governance capacity. This impact is connected to control, but not straightforwardly. Neither state control nor lack of it makes a metropolitan governance structure able to govern. The key is applying control in ways that are in harmony with the context. This context is wide and obscures such things as administrative structure, culture, traditions and general policies towards local authorities. It creates an invisible framework that defines which actors need to have a say in the establishment and development of metropolitan governance structures under the existing circumstances and what kind of governance structures could be realizable. Thus, the governance structure's status vis-à-vis the state must match with the administrative environment.

Altogether, the contextual reasons are a major factor why similar forms of control can enhance or reduce governance capacity in different metropolitan areas. In one metropolitan area, governance capacity can be achieved through direct state steering and, in another, through indirect control, such as financing a politically decentralized arrangement. However, complete lack of state presence seems to be problematic. State control forms a platform on which metropolitan governance capacity can evolve.

Incentives, disincentives, steering and/or financing make up different combinations of control mechanisms that are possible to implement in different contexts. However, based on this study, there are two features in the control relationship that define the existence or absence of metropolitan governance capacity in all the cases: state mandate and state support.

State mandate is the formal framework of the relationship between national level and metropolitan level actors. The mandate requires that the metropolitan arrangement undertakes specified activities or provides certain services (cf. Zimmerman 1987). State participation in the form of mandate is particularly important, when metropolitan governance structures are established. As Savitch and Kantor (2010) stated, high-level governments must impose metropolitan governance arrangements on local government.

State support is about generating and maintaining a legislative and regulative environment, in which metropolitan governance can take place. It is about long-term national urban policy, or at least a sense of continuity that makes broad-based and sustained metropolitan planning possible. State support is also the element that prepares the ground for the establishment of metropolitan governance structures and makes clear jurisdictions between metropolitan actors possible.

State mandate and support convert state control into metropolitan governance capacity. In addition, in many cases, the state cannot simply give a mandate for the establishment of a governance arrangement or sustainably support its operations. Once again, contextual reasons such as legislation, administrative culture, difficulties in achieving the approval of all the relevant metropolitan actors or prevailing power relations can prevent the state from giving a sufficient mandate or support to the metropolitan governance structure. In many cases, the context itself must evolve before a governance arrangement with capacity can be established (Haveri et al. 2018, p. 11). Changes in contextual factors, for example 
in political power relations, may also result in a situation in which the state withdraws its support or reverses the mandate. The importance of metropolitan areas can be seen as a threat for the state: strengthening political power at the metropolitan level can weaken the position of the central government in relation to other levels of government and hence hollow-out the state (cf. Lafortune and Collin 2011, pp. 400-1; Boudreau et al. 2007; Tomàs 2012; Beeri and Magnússon 2019). This may restrain the state's willingness to give a strong mandate to a metropolitan governance structure.

Altogether, the relationship between state control and metropolitan governance capacity manifests the complex and intertwined relationship between the state and the metropolitan areas: even the control relationship is interdependent rather than hierarchical.

Author Contributions: Conceptualization, H.T. and A.H.; methodology, H.T. and A.H.; validation, H.T. and A.H.; formal analysis, H.T. and A.H.; writing—original draft preparation, H.T. and A.H.; writing—review and editing, H.T. and A.H. All authors have read and agreed to the published version of the manuscript.

Funding: The authors received no financial support for the research, authorship, and/or publication of this article.

Conflicts of Interest: The authors declare no conflict of interest.

\section{References}

Aars, Jacob. 2005. Metropolitan Areas in Norway. Suburbanisation and political behavior. In Metropolitanization and Political Change. Edited by Vincent Hoffmann-Martinot and Jefferey Sellers. Wiebaden: VS Verlag für Sozialwissenscaften, pp. 141-58.

AMT. 2015. Conseil D'administration. Available online: https://www.amt.qc.ca/fr/a-propos/gouvernance (accessed on 11 September 2015).

Auckland Council. 2015. Available online: http://www.aucklandcouncil.govt.nz/EN/Pages/default.aspx (accessed on 26 May 2015).

Bartley, Brendan, and Kasey Treadwell Shine. 2005. Competitive city. Governance and the changing dynamics of urban Regeneration in Dublin. In The Globalized City. Economic Restructuring and Social Polarization in European Cities. Edited by Frank Moulaert, Arantxa Rodriguez and Erik Swyngedouw. Oxford: Oxford University Press, pp. 145-66.

Beeri, Itai, and Magnús Árni Skjöld Magnússon. 2019. Governance Relations in Small Nations: Competition vs. Cooperation and the Triple Role of Big Cities. Lex-Localis- Journal of Local Self-Government 17: 2. [CrossRef]

Boudreau, Julie-Anne, Pierre Hamel, Bernard Jouve, and Roger Keil. 2007. Constructing metropolitan political spaces: Montreal and Toronto. In Governing Metropolises. Profiles of Issues and Experiments on Four Continents. Edited by Jean-Pierre Collin and Mélanie Robertson. Québec: Presses de l'Université Laval.

Brenner, Neil. 2003. Metropolitan institutional reform and the rescaling of state space in contemporary Western Europe. European Urban and Regional Studies 10: 297-324. [CrossRef]

City of Oslo. 2008. Municipal Master Plan Oslo. Available online: http://www.oslo.kommune.no/getfile.php/ byr\%C3\%A5dsavdeling\%20for\%20finans\%20\%28FIN\%29/Internett\%20\%28FIN\%29/Dokumenter/2010\% 20-\%20og\%20f\%C3\%B8r/Kommuneplan\%202008\%20-\%20engelsk\%20versjon\%20med\%20bokmerker.pdf (accessed on 16 September 2016).

CMM. 2015. Available online: http://cmm.qc.ca/ (accessed on 29 November 2015).

Collin, Jean-Pierre, and Mariona Tomàs. 2004. Metropolitan governance in Canada or the persistence of institutional reforms. Urban Public Economics Review 1: 13-39.

Daugbjerg, Carsten, and Paul Fawcett. 2017. Metagovernance, network structure, and legitimacy: Developing a heuristic for comparative governance analysis. Administration $\mathcal{E}$ Society 49: 1223-45.

Davoudi, Simin. 2008. Conceptions of the city-region: A critical review. Proceedings of the Institution of Civil Engineers: Urban Design and Planning 161: 51-60. [CrossRef]

Derby, Mark. 2012. Local and Regional Government. In Te Ara-the Encyclopedia of New Zealand. Available online: http://www.TeAra.govt.nz/en/local-and-regional-government/sources (accessed on 29 November 2016).

Dexia. 2008. Sub-National Governments in the European Union-Organisation, Responsibilities and Finance. Paris: Dexia Editions.

DRA. 2015. Available online: www.dra.ie (accessed on 3 November 2015). 
Dublin City. 2008. Funding the Dublin City Region. Available online: http://www.dublincity.ie/YourCouncil/ AbouttheCouncil/CouncilSpendingRevenue/DocumenDo/FundingtheDublinCityRegion.pdf (accessed on 3 November 2015).

Goldsmith, Michael. 2002. Central control over local government-A Western European comparison. Local Government Studies 28: 91-112. [CrossRef]

Haveri, Arto, Helena Tolkki, Inga Nyholm, and Jenni Airaksinen. 2018. Sources of legitimacy in metropolitan governance: A comparative case study of governance structures. International Journal of Public Administration 42. [CrossRef]

Heinelt, Hubert, and Daniel Kübler. 2005. Conclusion. In Metropolitan Governance: Capacity, Democracy and the Dynamics of Place. Edited by Hubert Heinelt and Daniel Kübler. Milton Park: Routledge, pp. 188-201.

Jouvé, Bernard. 2002. Gouvernance métropolitaine en Europe: Essai de typologie. Ecole Nationale des Travaux Publics de l'État (France). Paper presented at Communication au XXXVIIIème Colloque annuel de l'Association de Science Régionale de Langue Française, Trois-Rivières, August 21-23.

Kartverket. 2015. Fylkes- og kommuneoversikt. Available online: http://www.kartverket.no/Kunnskap/Fakta-omNorge/Fylker-og-kommuner/Tabell/ (accessed on 15 December 2016).

Kommunal- og Moderniseringsdepartementet. 2006. Regionale Fortrinn-Regional Framtid. (2006-2007). Available online: http://www.regjeringen.no/nb/dep/kmd/dok/regpubl/stmeld/2006-2007/Stmeld-nr-12-20062007-.html?id=440990 (accessed on 16 December 2016).

Kübler, Daniel, and Hubert Heinelt. 2005. Metropolitan governance, democracy and the dynamics of place. In Metropolitan Governance: Capacity, Democracy and the Dynamics of Place. Edited by Hubert Heinelt and Daniel Kübler. Milton Park: Routledge, pp. 8-28.

Lafortune, Marie-Ève, and Jean-Pierre Collin. 2011. Building metropolitan governance capacity: The case of the Communauté Métropolitaine de Montréal. Canadian Public Administration/Administration Publique du Canada 54: 399-420. [CrossRef]

Lambert, Marie-Renée. 2008. Municipal Reforms and Metropolitan Governance. The Canadian Experience. Institute of Public Policy. Report. Available online: http://www.parliament.nz/resource/0000108360 (accessed on 15 December 2016).

Lefèvre, Christian. 1998. Metropolitan government and governance in Western Countries: A critical review. International Journal of Urban and Regional Research 22: 9-25. [CrossRef]

Loughlin, John. 2007. Reconfiguring the state: Trends in territorial governance in European states. Regional and Federal Studies 17: 385-403. [CrossRef]

Loughlin, John. 2009. The 'hybrid' state: Reconfiguring territorial governance in Western Europe. Perspectives on European Politics and Society 10: 51-68. [CrossRef]

McKinlay, Peter. 2011. Integration of urban services and good governance: The Auckland supercity project. Paper presented at Pacific Economic Cooperation (PECC) seminar on Environmental Sustainability in Urban Centres, Perth, Australia, April 13.

Memon, Pyar Ali, Tom Graham Davies, and Tom Fookes. 2007. Institutional arrangements for metropolitan government and strategic planning in Auckland. New Zealand Geographer 63: 43-54. [CrossRef]

MERA. 2015. Available online: http://www.mera.ie (accessed on 13 December 2016).

Ministry of Local Government and Modernisation. 2015. Available online: https://www.regjeringen.no/en/dep/ $\mathrm{kmd} / \mathrm{id} 504 /$ (accessed on 13 December 2016).

Mouat, Clare, and Jago Dodson. 2013. Reviewing the Auckland 'super city': Towards an ongoing agenda for evaluating super city governance. Australian Planner 50: 138-47. [CrossRef]

Næss, Petter, Teresa Næss, and Arvid Strand. 2009. The Challenge of Sustainable Mobility in Urban Planning and Development in Oslo Metropolitan Area. Report. TØI Report 1024/2009. Available online: http: //www.toi.no/getfile.php/Publikasjoner/T\%D8I\%20rapporter/2009/1024-2009/1024-2009-nett.pdf (accessed on 13 December 2016).

Nelles, Jen. 2013. Cooperation and capacity? Exploring the sources and limits of city-region governance partnerships. International Journal of Urban and Regional Research 37: 1349-67. [CrossRef]

NTA. 2015. Available online: http://www.nationaltransport.ie (accessed on 16 December 2016).

Nyholm, Inga. 2011. Kunta-valtio-suhteen muodonmuutos_Linjakkaasta liitosta monimuotoisten mekanismien määrittämäksi kokonaisuudeksi. In Kunnallisen Itsehallinnon Peruskivet. Edited by Jari Stenvall, Arto Haveri and Kaija Majoinen. Acta nro 224. Kuntaliiton verkkojulkaisu. Helsinki: Kuntaliitto, pp. 128-40. 
OECD. 2004. Territorial Reviews Montreal, Canada. Paris: OECD Publishing.

OECD. 2007. Territorial Review Norway. Paris: OECD Publishing.

OECD. 2015a. The Metropolitan Century: Understanding Urbanisation and Its Consequences. Paris: OECD Publishing. OECD. 2015b. Governing the City. Paris: OECD Publishing.

Oslo Kommune. 2015. Slik styres Oslo. Available online: https://www.oslo.kommune.no/politikk-ogadministrasjon/politikk/slik-styres-oslo/ (accessed on 27 December 2016).

Plansamarbeidet. 2015. Available online: http://plansamarbeidet.no/om-plansamarbeidet/ (accessed on 27 December 2016).

PMAD. 2012. Available online: http://pmad.ca/ (accessed on 13 December 2016).

Pollit, Christopher. 2006. Modernising government: A symposium. Editor's Introduction. International Review of Administrative Sciences 72: 307-8. [CrossRef]

Ragin, Charles C. 1987. The Comparative Method. Moving Beyond Qualitative and Quantitative Strategies. Berkeley and Los Angeles: University of California Press.

Rhodes, R.A.W. 1996. The new governance. Governing without government. Political Studies 44: 652-67. [CrossRef]

Ruter. 2015. Available online: https://ruter.no/om-ruter/ (accessed on 27 December 2016).

Salminen, Ari. 2007. Hallintovertailu ja vertailumallien käyttökelpoisuus. In Hallintovertailun Metodologia. Edited by Ari Salminen. Tutkimuksia 234. Hallintotiede 26. Vaasa: Vaasan yliopiston julkaisuja.

Samarbeidsalliansen Osloregionen. 2015. Available online: http://www.osloregionen.no (accessed on 27 December 2016).

Savitch, H. V. 2010. Rescaling for a global world. Progress in Planning 73: 11-16.

Savitch, H. V., and Paul Kantor. 2010. Are global city regions governable? Paper presented at 2010 Annual Meeting of the American Political Science Association, Toronto, Canada, 2-5 September.

Savitch, Hank, and Ronald K. Vogel. 2009. Regionalism and urban politics. In Theories of Urban Politics, Second Edition. Edited by J.S. Davies and D. Imbroscio. London: Sage, pp. 106-24.

Schneider, A. 2003. Decentralization: Conceptualization and measurement. Studies in Comparative International Development 38: 32-56. [CrossRef]

Sellers, Jefferey, and Vincent Hoffmann-Martinot. 2005. Introduction: Metropolitanization and political change. In Metropolitanization and Political Change. Edited by Vincent Hoffmann-Martinot and Jefferey Sellers. Wiebaden: VS Verlag für Sozialwissenscaften, pp. 11-16.

Sellers, Jefferey, and Anders Lidström. 2007. Decentralization, local government, and the welfare state. Governance: An International Journal of Policy, Administration, and Institutions 20: 609-32. [CrossRef]

Sohn, Christopphe, and Bernard Reitel. 2016. The role of national states in the construction of cross-border metropolitan regions in Europe: A scalar approach. European Urban and Regional Studies 23: 306-21. [CrossRef]

Statens Vegvesen. 2015. Oslopakke 3. Available online: http://www.vegvesen.no/Vegprosjekter/oslopakke3 (accessed on 27 December 2016).

Stoker, Gerry. 1998. Governance as Theory: Five Propositions. Unesco. Oxford: Blackwell.

Tomàs, Mariona. 2012. Exploring the metropolitan trap: The case of Montreal. International Journal of Urban and Regional Research 36: 554-67.

Treisman Daniel. 2007. The Architecture of Government: Rethinking Political Decentralization. Cambridge: Cambridge University Press.

Van den Berg, Leo, and Erik Braun. 1999. Urban competitiveness, marketing and the need for organising capacity. Urban Studies 36: 987-99. [CrossRef]

Ville de Montreal. 2015. Available online: http://ville.montreal.qc.ca/portal/page?_pageid=7737,98715570\&_dad= portal\&_schema=PORTAL (accessed on 13 December 2016).

Vogel, Ronald K. 2010. The city region as a new state space. Progress in Planning 73: 64-6.

Walsh, Cormac, and Brendan Williams. 2013. Metropolitan-hinterland relations in the Dublin city-region: Lessons from Germany. Administration 61: 133-53.

Whitehead, Mark. 2003. 'In the shadow of hierarchy': Meta-governance, policy reform and urban regeneration in the West Midlands. Area 35: 6-14. [CrossRef]

Zimmerman, Joseph F. 1987. The state mandate problem. State \& Local Government Review 19: 78-84.

(C) 2020 by the authors. Licensee MDPI, Basel, Switzerland. This article is an open access article distributed under the terms and conditions of the Creative Commons Attribution (CC BY) license (http://creativecommons.org/licenses/by/4.0/). 